\title{
Stand-alone totally thoracoscopic left atrial appendage exclusion using a novel clipping system in patients with high risk of stroke - initial experience and literature review
}

\author{
Piotr Suwalski ${ }^{1,2,3}$, Anna Witkowska ${ }^{1}$, Dominik Drobiński ${ }^{1}$, Joanna Rozbicka ${ }^{4}$, Sławomir Sypuła ${ }^{4}$, \\ Irena Liszka ${ }^{1}$, Radosław Smoczyński ${ }^{1}$, Jakub Staromłyński ${ }^{1}$, Irena Walecka ${ }^{5}$, Dariusz Kosior ${ }^{4}$ \\ ${ }^{1}$ Department of Cardiac Surgery, Central Clinical Hospital of the Ministry of Interior, Warsaw, Poland \\ ${ }^{2}$ Pulaski University of Technology and Humanities, Radom, Poland \\ ${ }^{3}$ Mossakowski Medical Research Centre, Polish Academy of Sciences, Warsaw, Poland \\ ${ }^{4}$ Department of Noninvasive Cardiology and Arterial Hypertension, Central Clinical Hospital of the Ministry of Interior, \\ Warsaw, Poland \\ ${ }^{5}$ Central Clinical Hospital of the Ministry of Interior, Warsaw, Poland
}

Kardiochirurgia i Torakochirurgia Polska 2015; 12 (4): 298-303

\begin{abstract}
Introduction: Atrial fibrillation (AF) is the most common clinically relevant arrhythmia and it is strongly associated with stroke. Left atrial appendage (LAA) is considered to be the most often source of thrombotic material. In recent decades a number surgical, percutaneous and hybrid approaches for LAA occlusion have been described revealing very different level of success and showing a variety of challenges associated with this matter. We present the first Polish experience with the stand-alone totally thoracoscopic LAA exclusion using novel clipping system.

Material and methods: Four patients (one male) in mean age of $74( \pm 13)$ years with long-standing persistent and chronic AF were admitted for totally thoracoscopic LAA exclusion. All patients had significant comorbidities and the history of the oral anticoagulation intolerance or suboptimal/unstable level $\left(\mathrm{CHA}_{2} \mathrm{DS}_{2}\right.$-VASC > 5, HAS_BLED > 3). Three procedures were performed through totally thoracoscopic access. In one patient due to massive adhesions in the left pleura we performed minithoracotomy in fourth left intercostal space. In two months follow-up we observed no mortality, no strokes and no bleedings.

Results: In all patient total exclusion of LAA with no residual remnant was confirmed. The "skin-to-skin" procedural time took on average 40 , minimum 20 minutes. Patients were extubated directly or within two hours after procedure. All patients were discharged early in a good condition.

Conclusions: Our initial first experience with the novel totally thoracoscopic clipping system for stand-alone LAA exclusion is very promising showing very high efficacy and good safety profile.
\end{abstract}

\section{Streszczenie}

Wstęp: Migotanie przedsionków to najczęściej występująca arytmia w populacji ludzkiej. Wiąże się ze zwiększonym ryzykiem wystąpienia udaru mózgu. Główne miejsce powstawania materiału zakrzepowo-zatorowego stanowi uszko lewego przedsionka (left atrial appendage - LAA). Na przestrzeni lat rozwinięto szereg chirurgicznych, przezskórnych i hybrydowych metod zamykania LAA. Ze względu na specyfikę tego obszaru terapie te wiążą się nadal jednak z szeregiem wyzwań i ograniczeń. W pracy przedstawiono pierwsze polskie doświadczenia z izolowanym całkowicie torakoskopowym zamknięciem LAA z użyciem nowego sytemu opartego na mechanizmie klipsowania.

Materiał i metody: Czterech pacjentów (1 mężczyzna) w średnim wieku 74 ( \pm 13 ) lat z przetrwałym, długo trwającym i utrwalonym migotaniem przedsionków zostało zakwalifikowanych do całkowicie torakoskopowego zamknięcia LAA. U wszystkich pacjentów występowały liczne obciążenia dodatkowe oraz nietolerancja lub niestabilny poziom antykoagulacji doustnej $\left(\mathrm{CHA}_{2} \mathrm{DS}_{2}\right.$-VASC $>5$, HAS_BLED > 3). U trzech pacjentów wykonano całkowicie torakoskopowe zamknięcie uszka lewego przedsionka. $U$ jednego pacjenta z powodu masywnych zrostów w lewej opłucnej niezbędne było wykonanie minitorakotomii lewostronnej w czwartym międzyżebrzu.

Wyniki: U wszystkich pacjentów przebieg śródoperacyjny oraz zamknięcie LAA przebiegało bez powikłań, z potwierdzonym całkowitym wykluczeniem jego światła. Średni czas operacji wyniósł 40 minut, najkrótszy to 20 minut. Pacjenci byli ekstubowani bezpośrednio po lub w przeciągu 2 godziny od zabiegu. Pacjenci zostali wypisani w dobrym stanie do domu we wczesnych dobach. W dwumiesięcznej obserwacji nie wystąpity zgony, udary ani krwawienia. 
Key words: LAA occlusion, atrial fibrillation, totally thoracoscopic.

\section{Introduction}

Atrial fibrillation (AF) is the most common clinically relevant arrhythmia, and it is strongly associated with stroke. The left atrial appendage (LAA) is the most frequent source of thrombotic material leading to cerebrovascular events [1]. Oral anticoagulation remains the standard of care of patients with AF. Current guidelines recommend such therapy when $\mathrm{CHA}_{2} \mathrm{DS}_{2}$-VASc exceeds $1[2,3]$. Recent publications indicate that LAA closure might not be inferior to oral anticoagulation in patients in whom it is not recommended [4]. Current guidelines of the European Society of Cardiology reflect this position, indicating that LAA closure in this group of patients (elevated $\mathrm{CHA}_{2} \mathrm{DS}_{2}-\mathrm{VASC}$ and/or HAS-BLED with contraindications for oral anticoagulation)

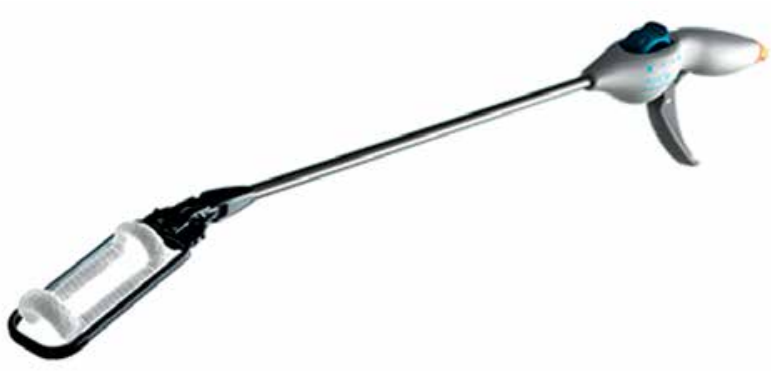

Fig. 1. AtriClip PRO LAA Exclusion System (courtesy of AtriClip, AtriCure, Dayton, OH, USA)

Tab. I. Patient characteristics

\begin{tabular}{lc}
\hline Age, mean \pm SD, years & $74 \pm 13$ \\
\hline Arterial hypertension, no & 3 \\
\hline Diabetes mellitus, no & 3 \\
\hline Stable coronary artery disease, no & 2 \\
\hline Chronic obstructive pulmonary disease, no & 1 \\
\hline Chronic renal disease, no & 3 \\
\hline Cardiomyopathy, no & 1 \\
\hline Stroke/transient ischemic attack, no & 1 \\
\hline Pacemaker/implantable cardioverter-defibrillator, no & 1 \\
\hline Chronic liver failure, no & 1 \\
\hline Coagulopathy, no & 2 \\
\hline Morbid obesity (BMI > 30), no & 2 \\
\hline Mean left atrium diameter, mm & $47 \pm 2$ \\
\hline Mean left ventricle ejection fraction, \% & $48 \pm 11$ \\
\hline
\end{tabular}

Wnioski: Pierwsze polskie doświadczenia z całkowicie torakoskopowym systemem do zamykania uszka lewego przedsionka wskazują na wysoką skuteczność oraz bezpieczeństwo tej metody leczenia u pacjentów wysokiego ryzyka udaru mózgu. Słowa kluczowe: zamknięcie LAA, całkowicie torakoskopowo, migotanie przedsionków.

may be recommended [2, 3]. In recent decades a number of surgical, percutaneous and hybrid approaches for LAA occlusion have been described, revealing very different levels of success and showing a variety of challenges associated with this issue.

We present the first Polish experience with the new clipping system for totally thoracoscopic LAA exclusion.

\section{Material and methods}

The device for surgical totally thoracoscopic left atrial appendage occlusion AtriClip PRO LAA Exclusion System (AtriClip, AtriCure, Dayton, OH, USA) consists of an automatically closing clip placed in a deployment loop on a disposable holder with head articulation of 60 degrees sideto-side and up/down (Fig. 1). The several novel features of the system in comparison to previous ones, such as its length, maneuverability and releasing system, enable it to be used in a totally thoracoscopic fashion. The AtriClip PRO has parallel titanium crossbars that equalize the force over the tissue trabeculations of the LAA during deployment, ensuring a sealed line at the base of the LAA orifice, as was confirmed in preclinical and clinical studies [5]. The clip can be opened and closed repeatedly before final deployment.

Four patients (one man, three women) at mean age of 74 ( \pm 13 ) years with long-standing persistent and chronic atrial fibrillation were admitted to our department for totally thoracoscopic left atrial appendage (LAA) exclusion in order to reduce the risk of stroke and complications of inadequate anticoagulation. All patients had significant comorbidities (Table I) and a history of oral anticoagulation intolerance or a suboptimal/unstable level. The mean left ventricle ejection fraction was $48 \%$ ( $\pm 11 \%)$, and the mean left atrial diameter was $47 \mathrm{~mm}( \pm 2 \mathrm{~mm})$. The minimal $\mathrm{CHA}_{2} \mathrm{DS}_{2}$-VASC score was 5 and the HAS-BLED score was over 3 , in one patient reaching 7 points (Table II). All patients prior to the operation underwent transesophageal echocardiography (TEE) to rule out thrombus in the LAA.

The patients were placed in the supine position and were intubated under general anesthesia with a double lumen intratracheal tube. Transesophageal echocardiogra-

Tab. II. Risk scores

\begin{tabular}{lcc} 
No. & $\mathrm{CHA}_{2} \mathrm{DS}_{2}-\mathrm{VASC}$ Score & HAS-BLED Score \\
1 & 5 & 4 \\
\hline 2 & 5 & 3 \\
\hline 3 & 7 & 7 \\
\hline 4 & 8 & 3 \\
\hline
\end{tabular}




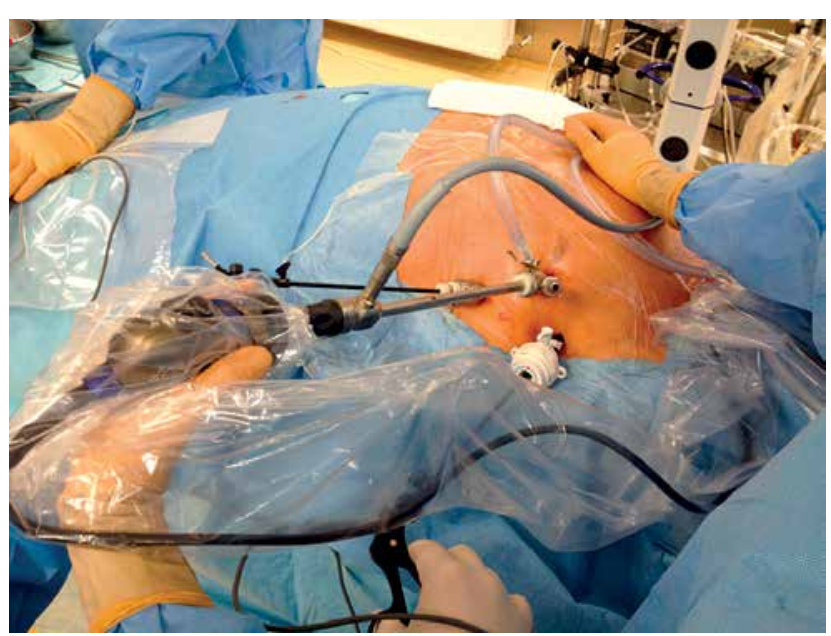

Fig. 2. Thoracoscopic ports placement on the left side of the chest

phy probe was introduced. Single right lung ventilation was started. Subsequently, 3 thoracoscopic ports were placed - one through the fourth intercostal space in the anterior axillary line (for the endoscopic camera), and two through the third and sixth intercostal spaces at the midaxillary line into the left pleura (working ports) (Fig. 2). Working space was created with $\mathrm{CO}_{2}$ insufflation. Pericardiectomy was performed parallel to the phrenic nerve to visualize the LAA, beneath the nerve in 3 patients and above in one patient. Stay sutures were placed on the lower edge of the pericardium for better access to the LAA. If necessary one stay suture on the upper edge of the pericardium was added (Fig. 3). The diameter of the base of the LAA was measured with a dedicated selection guide (Fig. 4). The AtriClip PRO was introduced through the incision in the sixth intercostal space enlarged to $2-3 \mathrm{~cm}$. Under TEE control it was deployed at the base of the left atrial appendage with special care in order not to leave any residual stump (Fig. 5). The possibility of repeated opening of the clip before the final deployment enabled correction of its position if the intraoperative echocardiography showed incomplete
LAA closure or an LAA remnant. Full LAA exclusion was confirmed with TEE visualization (Fig. 6). In one patient due to massive adhesions in the left pleura totally thoracoscopic access was not possible. We performed minithoracotomy in the fourth left intercostal space laterally to the mammary line. By gentle dissection, the direct visualization of the LAA was easily achieved. The AtriClip PRO was deployed through minithoracotomy without further complications (Fig. 7). The skin-to-skin procedural time took on average 40, minimum 20 minutes.

\section{Results}

The perioperative period was uneventful. Two first patients were extubated two hours after the procedure. The two next patients were extubated directly after the procedure in the operating room. Except for one patient with extreme coagulopathy due to chronic liver failure chest tubes were removed on the first postoperative day. Three patients were discharged home on the second or third postoperative day in a good condition. One patient due to many extracardiac comorbidities required longer stay without any additional complications and was discharged in a good condition on the sixth postoperative day.

During two months of follow-up we observed no bleeding events, no strokes, and no mortality. Echocardiography monitoring showed good and stable clip position. Further imaging with computed tomography is planned.

\section{Discussion}

The recommendations for the LAA exclusion have been widened over recent years, but still there are many questions to be answered. In previous decades cardiac surgery was the only source of knowledge in this area; it revealed a number of challenges associated with this apparently easy task of closing or excluding a small appendage within the left atrium. In recent years a few percutaneous and hybrid technologies have been introduced, showing good efficacy, but also confirmed the "old" difficulties, mainly as-

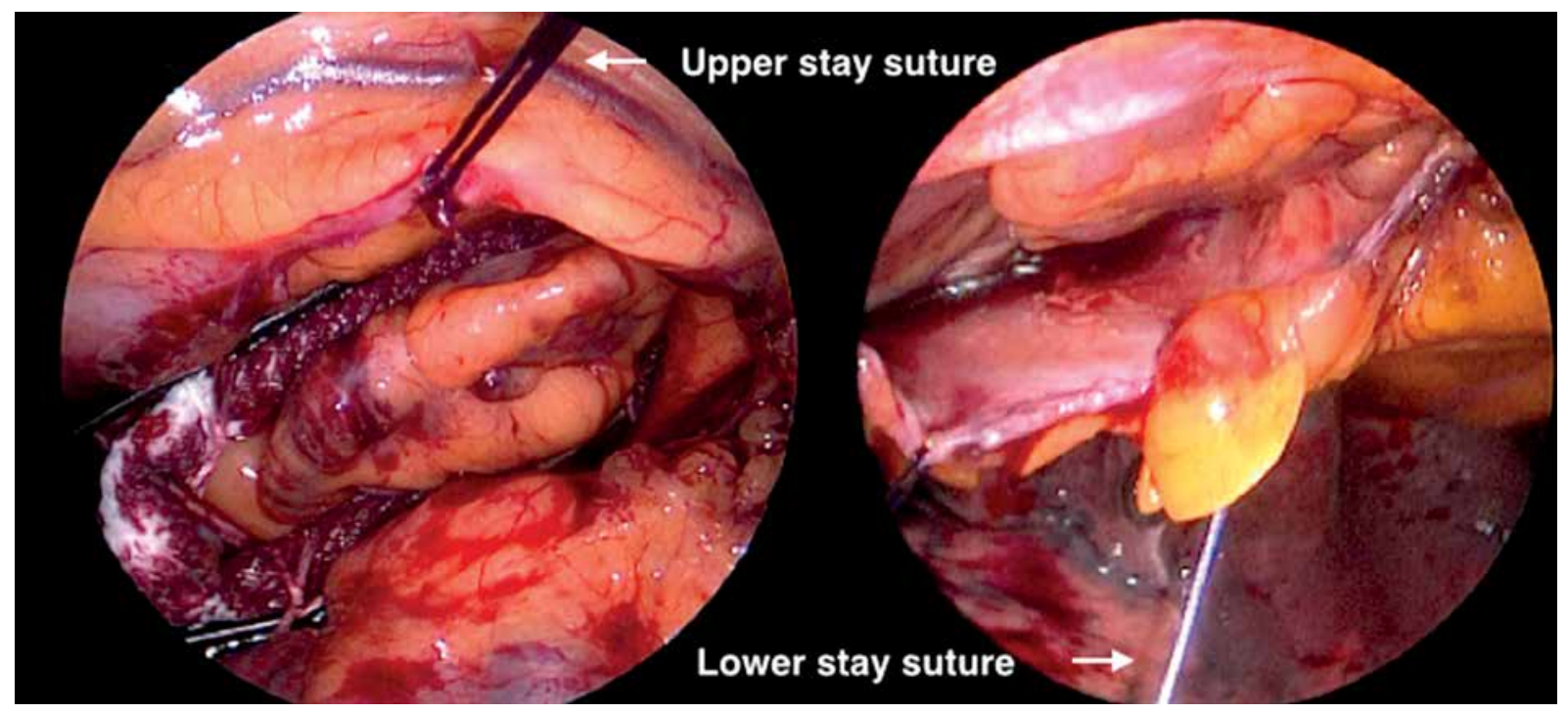

Fig. 3. Stay sutures and access to left atrial appendage 
sociated with the auricle's fragility, and variable anatomy of the LAA orifice, causing difficulties with device matching and thrombogenic potential of implanted devices [4, 6]. The possible complications include LAA tear, pericardial effusion or tamponade requiring drainage or surgery, acute stroke due to air or thrombus, device embolization or infection requiring its removal and incomplete closure or a leak to the LAA after the procedure $[4,7,8]$. An overlooked issue is long exposure to $\mathrm{X}$-ray radiation and high volume contrast infusion during the percutaneous procedure, whose long-term influence remains unexamined. The problem mainly associated with surgical approaches was the late recanalization, while incomplete closures were more typical for percutaneous techniques and were strictly associated with LAA anatomy, which is currently one of the most important parameters in qualifying a patient for such a procedure $[5,9,10]$. The game remains risky since it has been proven that incomplete LAA closure increases the risk of stroke to a higher level than leaving it open [5]. Also a stump of LAA bigger than $1 \mathrm{~cm}$ is considered to be thrombogenic [11].

Another major question arose regarding generally the clinical relevance of such a procedure in large cohorts. To date, only one large trial has allowed the conclusion that effective LAA exclusion prevents stroke, although the level of total occlusion in this trial was far from ideal [4].
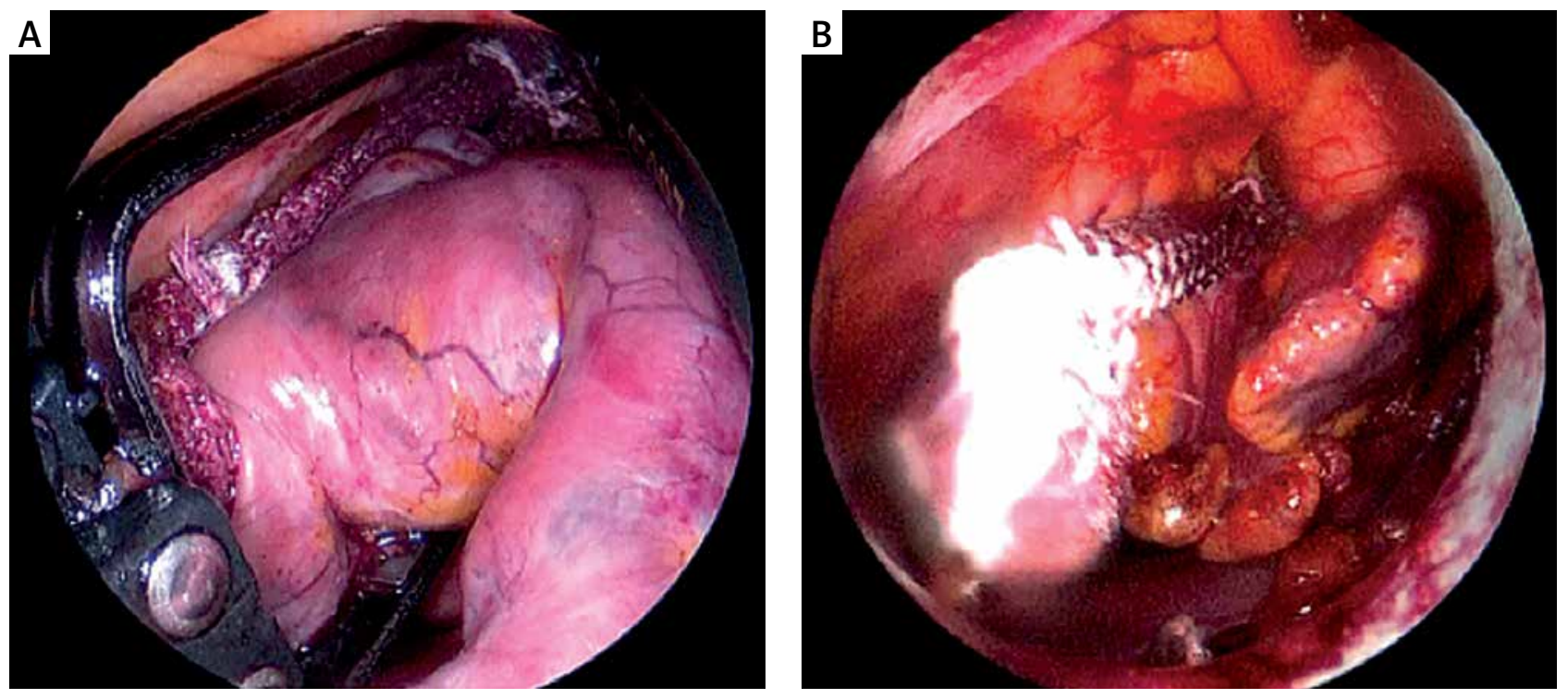

Fig. 5. Fully deployed AtriClip PRO
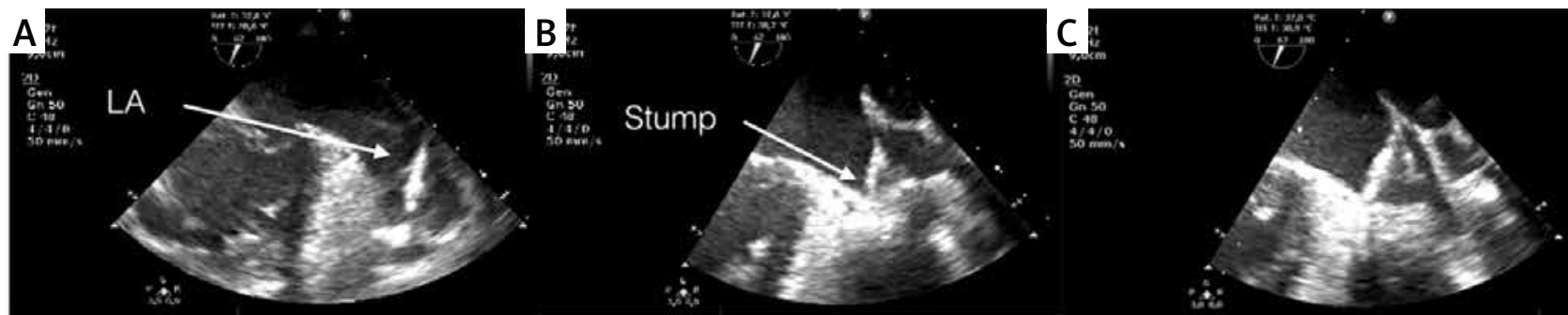

Fig. 6. Intraoperative transesophageal echocardiographic monitoring. Left atrial appendage (A). Incomplete occlusion of the left atrial appendage (LAA) orifice (B). Full LAA exclusion after repositioning (C) 


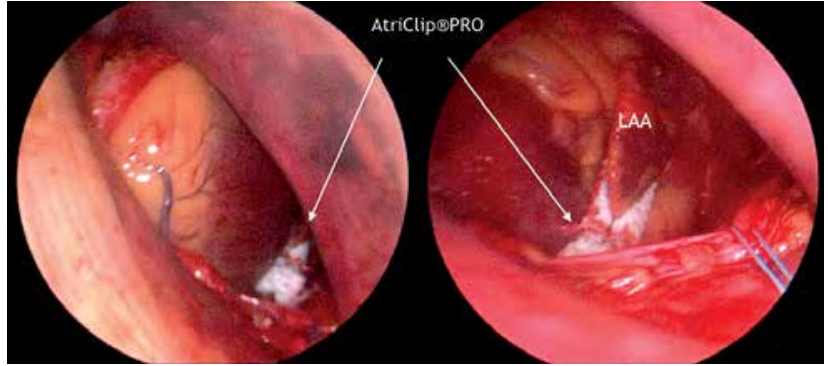

Fig. 7. Minithoracotomy. AtriClip PRO at the base of left atrial appendage (LAA)

persistent atrial fibrillation. The published data show that up to $100 \%$ efficacy with total LAA exclusion, both in short-term and observation over a few years, is possible [9-12]. Furthermore, apart from the excellent efficacy, no early or late complications such as bleeding, pericardial effusion, device malposition, or infection within 3 years have been revealed and, what is of utmost importance, no stroke was observed during this period although the mean $\mathrm{CHADS}_{2}$-VASC score was 4 (about $10 \%$ yearly stroke risk) and half of the patient group was off oral anticoagulation therapy. No bleeding incident occurred during this observation [13].

In the technologies used to date, the anatomy of the left atrial appendage has been a crucial factor influencing the results, but also one contraindicating the percutaneous procedure in some situations. The simplicity of the Atriclip system makes it totally independent from the LAA anatomy. It is also important that during the procedure the clip can be repeatedly reopened and repositioned under the simultaneous transesophageal control in case of any suspicion of incomplete occlusion or remnant, in order to achieve the optimal result. The problem of recanalization or residual leak has been recently raised for surgical LAA closure within the left atrium. In none of our cases was the LAA remnant (stump) bigger than $1 \mathrm{~cm}$ or a leakage to the excluded LAA observed, which was an important finding taking into account that their presence significantly increases the risk of stroke (even more than leaving the LAA open) and which may be some limitation of other technologies $[14,15]$. Also in a prospective study of an epicardial device for LAA closure there was no remnant or residual leak in long-term follow-up [13]. What should be emphasized is that the implantation of the AtriClip system does not require $X$-ray radiation or intravenous contrast administration, which might be a significant advantage since very many patients qualified for LAA exclusion are multimorbid, with impaired renal function. The access site is reduced to three $1-2 \mathrm{~cm}$ incisions on the left side of the chest. The procedural skin-to-skin time reaches less than 40 minutes and patients are extubated at once after the operation. Patients can be discharged from the hospital on the second or third postoperative day. From the practical point of view it is important that the implantation setup does not require an X-ray arm or hybrid operating room, although
Tab. III. Advantages of the procedure

\begin{tabular}{ll}
\hline 1 & Very high safety profile \\
\hline 2 & $\begin{array}{l}\text { Up to } 100 \% \text { efficacy in total LAA exclusion including long-term } \\
\text { follow-up }\end{array}$ \\
\hline 3 & Independence from LAA anatomy \\
\hline 4 & Totally thoracoscopic, beating heart procedure \\
\hline 5 & $\begin{array}{l}\text { Very short (mean 40, minimum in our hands } 20 \text { minutes) } \\
\text { procedure }\end{array}$ \\
\hline 6 & Extubation “on-table" \\
\hline 7 & Short 2-3 day hospital stay \\
\hline LAA - left atrial appendage
\end{tabular}

close cooperation with an experienced echocardiographer is recommended.

Limitations of the procedure are few, but still its invasiveness should be mentioned. A history of surgery within the pericardium and/or left pleural cavity as well as the presence of thrombus within the LAA are contraindications for totally thoracoscopic LAA clipping. The advantages of the procedure are presented in Table III. Due to the balance between the advantages and disadvantages of surgical thoracoscopic and percutaneous approaches (similarly to the field of persistent atrial fibrillation ablation) a prospective randomized trial may be recommended.

Additionally, electrical isolation of the LAA from the left atrium accompanying the implementation of the Atriclip was described. In a few cases it was associated with the cure of atrial fibrillation [16].

\section{Conclusions}

It may be concluded that stand-alone LAA exclusion/ occlusion opens new very interesting, promising but also challenging perspectives. Cardiac surgeons in cooperation with cardiologists should further participate in this progress since they also have good tools. The PROTECT AF trial has guided the way towards the new indication and therapeutic option, and further clinical research has to be undertaken.

Our first experience with the new totally thoracoscopic LAA clipping system is very promising, showing very high efficacy and a good safety profile. Further studies are warranted.

\section{Disclosure}

Authors report no conflict of interest.

\section{References}

1. Frost L, Engholm G, Johnsen S, Moller H, Husted S. Incident stroke after discharge from the hospital with a diagnosis of atrial fibrillation. Am J Med 2000; 108: 36-40.

2. European Heart Rhythm Association; European Association for Cardio-Thoracic Surgery, Camm AJ, Kirchhof P, Lip GY, Schotten U, Savelieva I, Ernst S Van Gelder IC, Al-Attar N, Hindricks G, Prendergast B, Heidbuchel H, Alfieri O, Angelini A, Atar D, Colonna P, De Caterina R, De Sutter J, Goette A, Gorenek B, Heldal M, Hohloser SH, Kolh P, Le Heuzey JY, Ponikowski P, Rutten $\mathrm{FH}$. Guidelines for the management of atrial fibrillation: the task force for the management of atrial fibrillation of the European Society of Cardiology (ESC). Eur Heart J 2010; 31: 2369-2429. 
3. European Heart Rhythm Association; European Association for Cardio-Thoracic Surgery, Camm AJ, Kirchhof P, Lip GY, Schotten U, Savelieva I, Ernst S, Van Gelder IC, Al-Attar N, Hindricks G, Prendergast B, Heidbuchel H, Alfieri O, Angelini A, Atar D, Colonna P, De Caterina R, De Sutter J, Goette A, Gorenek B, Heldal M, Hohloser SH, Kolh P, Le Heuzey JY, Ponikowski P, Rutten FH; ESC Committee for Practice Guidelines. Guidelines for the management of atrial fibrillation: the Task Force for the Management of Atrial Fibrillation of the European Society of Cardiology (ESC). Europace 2010; 12 : 1360-1420.

4. Holmes DR, Reddy VY, Turi ZG, Doshi SK, Sievert H, Buchbinder M, Mullin CM, Sick P; PROTECT AF Investigators. Percutaneous closure of the left atrial appendage versus warfarin therapy for prevention of stroke in patients with atrial fibrillation: a randomised non-inferiority trial. Lancet 2009; 374: 534-542.

5. Kanderian AS, Gillinov AM, Pettersson GB, Blackstone E, Klein AL. Success of surgical left atrial appendage closure: assessment by transesophageal echocardiography. J Am Coll Cardiol 2008; 52: 924-929.

6. Bartus K, Han FT, Bednarek J, Myc J, Kapelak B, Sadowski J, Lelakowski J, Bartus S, Yakubov SJ, Lee RJ. Percutaneous left atrial appendage suture ligation using the LARIAT device in patients with atrial fibrillation: initial clinical experience. J Am Coll Cardiol 2013; 62: 108-118.

7. Holmes DR, Kar S, Price MJ, Whisenant B, Sievert H, Doshi SK, Huber K, Reddy VY. Prospective randomized evaluation of the Watchman Left Atrial Appendage Closure device in patients with atrial fibrillation versus longterm warfarin therapy: the PREVAIL trial. J Am Coll Cardiol 2014; 64: 1-12.

8. Han FT, Bartus K, Lakkireddy D, Rojas F, Bednarek J, Kapelak B, Bartus M, Sadowski J, Badhwar N, Earnest M, Valderrabano M, Lee RJ. The effects of LAA ligation on LAA electrical activity. Heart Rhythm 2014; 11: 864-870.

9. Ailawadi G, Gerdisch MW, Harvey RL, Hooker RL, Damiano RJ Jr, Salamon T, Mack MJ. Exclusion of the left atrial appendage with a novel device: early results of a multicenter trial. J Thorac Cardiovasc Surg 2011; 142: 1002-1009, 1009.e1001.
10. Salzberg SP, Plass A, Emmert MY, Desbiolles L, Alkadhi H, Grunenfelder Genoni M. Left atrial appendage clip occlusion: early clinical results. J Thorac Cardiovasc Surg 2010; 139: 1269-1274.

11. Contractor T, Khasnis A. Left Atrial Appendage Closure in Atrial Fibrillation: A World without Anticoagulation? Cardiol Res Pract 2011; 2011: 752808.

12. Salzberg SP, Gillinov AM, Anyanwu A, Castillo J, Filsoufi F, Adams DH. Surgical left atrial appendage occlusion: evaluation of a novel device with mag netic resonance imaging. Eur J Cardiothorac Surg 2008; 34: 766-770.

13. Emmert MY, Puippe G, Baumüller S, Alkadhi H, Landmesser U, Plass A, Bettex D, Scherman J, Grünenfelder J, Genoni M, Falk V, Salzberg SP. Safe, effective and durable epicardial left atrial appendage clip occlusion in patients with atrial fibrillation undergoing cardiac surgery: first long-term results from a prospective device trial. Eur J Cardiothorac Surg 2014; 45: 126-131.

14. Di Biase L, Santangeli P, Anselmino M, Mohanty P, Salvetti I, Gili S, Horton R, Sanchez JE, Bai R, Mohanty S, Pump A, Cereceda Brantes M, Gallinghouse GJ, Burkhardt JD, Cesarani F, Scaglione M, Natale A, Gaita F. Does the left atrial appendage morphology correlate with the risk of stroke in patients with atrial fibrillation? Results from a multicenter study. J Am Coll Cardiol 2012; 60: 531-538

15. Pillarisetti J, Reddy YM, Gunda S, Swarup V, Lee R, Rasekh A, Horton R, Massumi A, Cheng J,Bartus K, Badhwar N, Han F, Atkins D, Bommana S, Earnest M, Nath J, Ferrell R, Bormann S, Dawn B, Di Biase L, Mansour M, Natale A, Lakkireddy D. Endocardial (Watchman) vs epicardial (Lariat) left atrial appendage exclusion devices: Understanding the differences in the location and type of leaks and their clinical implications. Heart Rhythm 2015; 12: 1501-1507.

16. Di Biase L, Burkhardt JD, Mohanty P, Sanchez J, Mohanty S, Horton R, Gallinghouse GJ, Bailey SM, Zagrodzky JD, Santangeli P, Hao S, Hongo R, Beheiry S, Themistoclakis S, Bonso A, Rossillo A, Corrado A, Raviele A, Al-Ahmad A, Wang P, Cummings JE, Schweikert RA, Pelargonio G, Dello Russo A Casella M, Santarelli P, Lewis WR, Natale A. Left atrial appendage: an underrecognized trigger site of atrial fibrillation. Circulation 2010; 122: 109-118. 